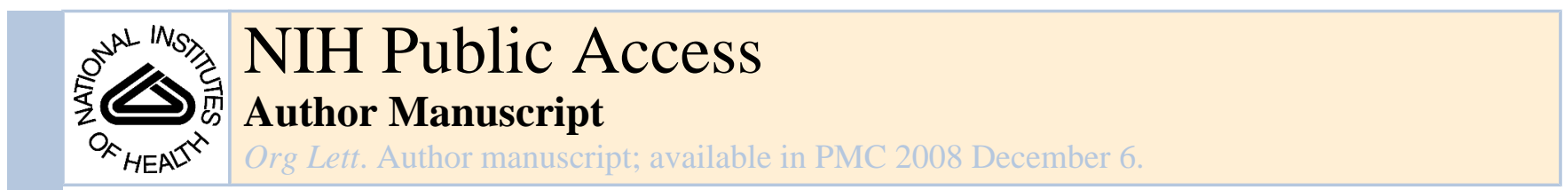

Published in final edited form as:

Org Lett. 2007 January 4; 9(1): 165-167. doi:10.1021/o10627810.

\title{
Silver(I) Triflate-Catalyzed Direct Synthesis of $N$-PMP Protected a-Aminopropargylphosphonates from Terminal Alkynes
}

\author{
Rajasekhar Dodda and Cong-Gui Zhao \\ Department of Chemistry, University of Texas at San Antonio, One UTSA Circle, San Antonio, Texas \\ 78249-0698
}
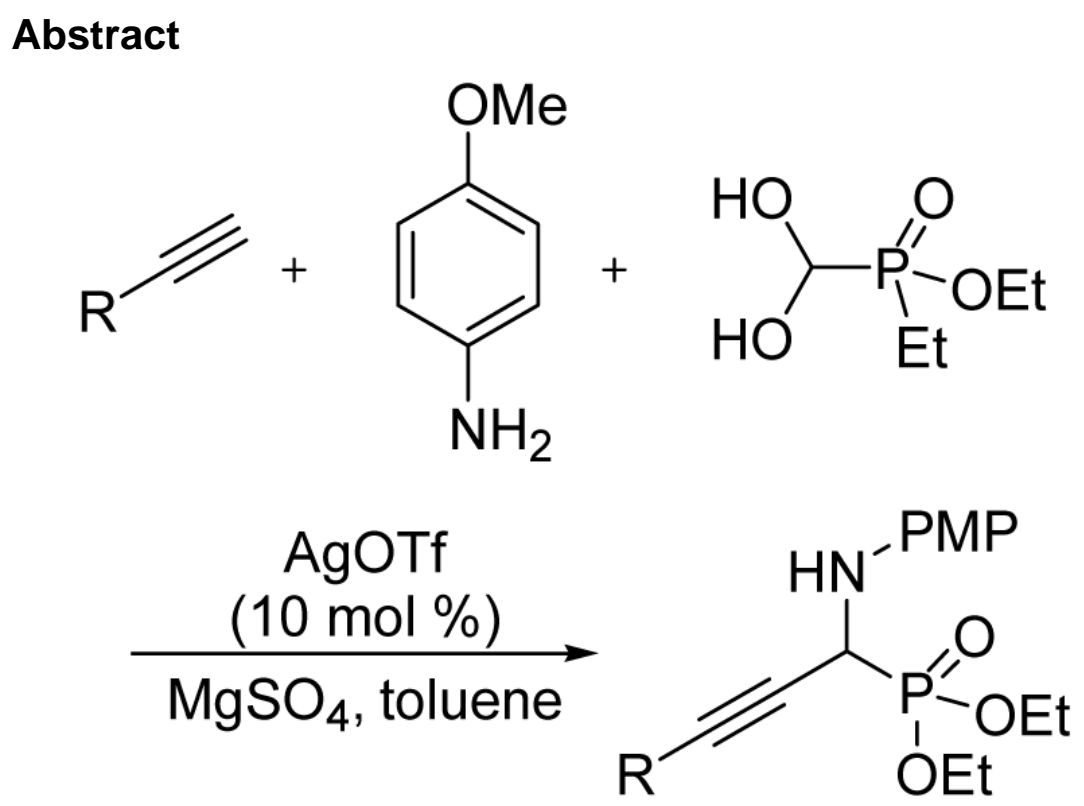

N-PMP protected $\alpha$-aminopropargylphosphonates have been synthesized by using a silver(I) triflatecatalyzed onepot three-component reaction of terminal alkynes, $p$ and diethyl formylphosphonate hydrate. Good to excellent yields of the desired products may be obtained with a very simple procedure.

Since $\alpha$-aminophosphonate derivatives are structural mimics of $\alpha$-amino acids, some of these compounds exhibit very high potency in inhibiting the enzymes that are involved in the metabolism of the corresponding amino acids. These compounds have already been found to act as antibacterial agents, neuroactive compounds, anticancer drugs and pesticides, with some of them being already commercialized. ${ }^{1}$ For example, Strater and Lipscomb have reported several L-leucine-phosphonic acid derivatives that are among the most potent low-molecular inhibitors of leucine aminopeptidase. ${ }^{2}$ Altered activity of such enzyme has been associated with HIV infections and several pathological disorders including cancer and cataracts. ${ }^{3}$

Due to their biological significance, many synthetic methods have been developed for these compounds. ${ }^{1}$ Among these reported methods, the Mannich-type addition of a phosphorus

cong.zhao@utsa.edu.

Supporting Information Available

Detailed experimental procedures and NMR spectra for all new compounds. This material is available free of charge via Internet at http://pubs.acs.org. 
nucleophile to an imine represents the most efficient way to obtain $\alpha$-aminophosphonate derivatives. ${ }^{1,4}$ Because of our recent interest in the synthesis of $\alpha$-hydroxyphosphonate ${ }^{5}$ and $\alpha$-aminophosphonate derivatives, we envisaged that $\alpha$-aminopropargylphosphonates are very good precursors for the synthesis of other $\alpha$-aminophosphonate derivatives, as the triple bond may be readily elaborated to introduce other functional groups. For example, this bond may be partially or totally saturated through selective hydrogenation. Furthermore, these compounds may have some interesting biological activities by themselves, although they have never been explored for this purpose. Nevertheless, the synthesis of these interesting compounds was only sporadically mentioned in the literature. ${ }^{6,7}$ After a careful literature search, only two related examples were found: In one case, Steglich and co-workers reported an addition of phenylacetylenylmagnesium bromide to a protected $\alpha$-iminophosphonate to produce the corresponding $\alpha$-aminopropargylphosphonate in poor yield $(20 \%) .{ }^{6}$ In the other case, Maas and co-workers obtained some $\alpha$-aminopropargylphosphine oxides as side products by reacting phosphane with $\alpha$-alkynyl iminium salts. ${ }^{7}$ To the best of our knowledge, no general synthetic method has ever been developed for the synthesis of $\alpha$-aminopropargylphosphonates.

Metal-catalyzed addition of terminal alkynes to imines, which are either preformed or in-situ generated from aldehydes and amines, represents one of the most convenient methods for the synthesis of propargylamines. ${ }^{8}$ Recently, this reaction has been successfully applied by the Chan's group for the synthesis of $\alpha$-aminopropargylcarboxylates from $\alpha$-imino esters. ${ }^{9}$ These reports prompted us to study the possibility of synthesizing $\alpha$-aminopropargylphosphonates through a metal-catalyzed addition of terminal alkynes to $\alpha$-iminophosphonates. Herein, we wish to report our preliminary results on a silver(I) triflate-catalyzed one-pot three-component reaction for the direct synthesis of $N$-PMP protected $\alpha$-aminopropargylphosphonates from terminal alkynes.

We first studied the silver(I) triflate catalyzed reaction of phenylacetylene (1a) and diethyl [(4methoxyphenyl)imino]-methylphosphonate (2). ${ }^{10}$ To our pleasure, the desired $N$-PMPprotected $^{11} \alpha$-aminopropargylphosphonate 3a was obtained in excellent yield (96\%, Eq 1).
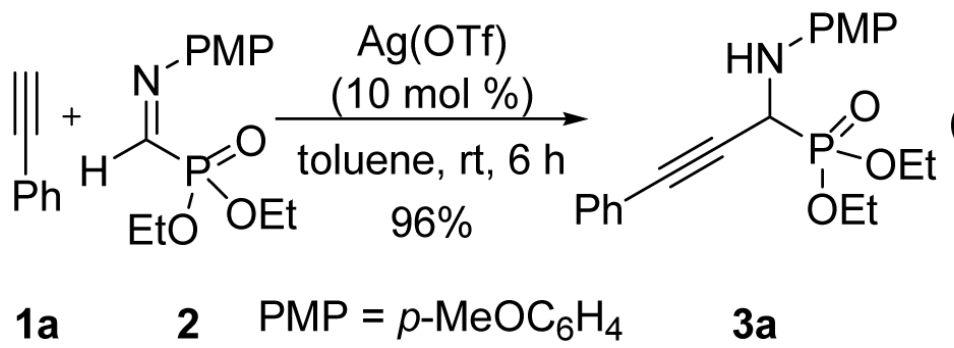

$3 a$

In view that the imine $\mathbf{2}$ has to be prepared every time freshly from $p$-anisidine (4) and the corresponding $\alpha$-formylphosphonate hydrate $(\mathbf{5}),{ }^{10}$ a one-pot three-component reaction with the in-situ formation of $\mathbf{2}$ would be more convenient. Thus, by using 4,5 and $\mathbf{1 a}$ as the substrates, we screened several transition-metal catalysts, which are known 8,9 for their ability in activating the terminal alkynes, in an effort to develop an efficient one-pot synthesis. The results are summarized in Table 1 .

As shown in Table $1, \mathrm{Zn}(\mathrm{II})$ triflate, $\mathrm{In}(\mathrm{III})$ triflate, and $\mathrm{Ag}(\mathrm{I})$ acetate do not catalyze the desired reaction (entry 1). Similarly, copper(II) bromide, copper(I) halides, silver(I) nitrate and silver (I) iodide prove to be poor catalysts for this reaction (entry 2). In contrast, scandium(III) and copper(II) triflates as well as the toluene complex of copper(I) triflate do catalyze the desired reaction, albeit in low efficiency (entries 3 to 5). Silver(I) triflate turned out still the best catalyst for the in situ mode, as the highest yield of 3a (62\%) was obtained (entry 6). Among the common organic solvents, toluene proved to be the best one for this reaction, whereas hexane 
(entry 7), dichloromethane (entry 8), dioxane (entry 9) and acetonitrile (entry 10) all gave inferior yields. Nonetheless, even under these optimized conditions (entry 6), the yield was not yet comparable to that of the isolate imine (Eq. 1)). We speculated that the differences in the reaction efficiency between this in-situ generated and the preformed $\alpha$-iminophosphonate (2) were due to the inevitable production of water under the in situ conditions, as water may cause the formed $\mathbf{2}$ to hydrolyze back to the starting formylphosphonate (5) under the action of the catalyst, which is also a Lewis acid. On the basis of this assumption, we intentionally added some drying agents into the reaction mixture in an attempt to remove the water. To our pleasure, the yield of 3a was indeed increased to $78 \%$ when $4 \AA$ molecular sieves were added (entry 11). Moreover, the reaction time was shortened to $6 \mathrm{~h}$ from $12 \mathrm{~h}$. Similar yield may also be achieved with sodium sulfate (entry 12). The most efficient combination proved to be silver(I) triflate and magnesium sulfate, as an excellent yield of $94 \%$ of the product may be obtained (entry 13). This result is similar to that of the preformed $\alpha$-iminophosphonate.

To understand the scope this new reaction, various terminal alkynes were studied as the substrates and the results are summarized in Table 2. As is evident from Table 2, besides phenylacetylene (entry 1), other arylsubstituted alkynes are also good substrates for this reaction. For example, all mono- halogenated phenylacetylenes produce excellent yields (e81\%) of the desired aminopropargylphosphonates (entries 2-5). Interestingly, acetylenes with both electron-withdrawing groups (entries 2-6) and electron-donating groups (entries 7-9) on the phenyl ring give the expected products in good yields, with the exception of the 3,5difluorophenyl derivative, which generate the product (3j) in slightly lower yield (entry 10). 1-Ethynylnaphthalene also participates in this reaction, and the desired product (3k) was isolated $61 \%$ yield (entry 11 ).

Nonetheless, aliphatic terminal alkynes react very slowly under these one-pot conditions and lead to lower yields. These products are better synthesized with the preformed imine $\mathbf{2}$. In this way, a 72\% yield may be obtained for the product (3I) of 1-heptyne. The products of 4phenyl-1-butyne (1m) and an acetyl-protected $\alpha$-hydroxyalkyne (1n) were similarly obtained (entries 13 and 14).

In summary, we have developed the first general method for the synthesis of $N$-PMP-protected $\alpha$-aminopropargylphosponates by using a silver(I) triflate-catalyzed one-pot three-component reaction of terminal alkynes with aromatic substituents, $p$-anisidine and diethyl

formylphosphonate hydrate. For aliphatic alkynes, the imine needs to be preformed. Good to excellent yields of the desired product may be obtained with a very simple operation procedure.

\section{Supplementary Material}

Refer to Web version on PubMed Central for supplementary material.

\section{Acknowledgment}

The authors thank the Welch Foundation (Grant No. AX-1593) and the NIH-MBRS program (Grant No. S06 08194 ) for the generous financial support of this research.

\section{References}

1. Kuhkar, VP.; Hudson, HR., editors. Aminophosphonic and Aminophosphinic Acids. John Wiley \& Sons; Chichester: 2000. For reviews, see: (b) Kafarski P, Lejczak B. Curr. Med. Chem.-Anti- Cancer Agents 2001;1:301-312. (c) Berlicki L, Kafarski P. Curr. Org. Chem 2005;9:1829-1850.

2. Strater N, Lipscomb WN. Biochem 1995;34:9200-9210. [PubMed: 7619821] 
3. (a) Umezawa H. Recent Results Cancer Res 1980;75:115-125. [PubMed: 7232823] (b) Taylor A, Daims MA, Lee J, Surgenor T. Curr. Eye Res 1982;2:47-56. [PubMed: 6813027] (c) Pulido-Cejudo G, Conway B, Proulx P, Brown R, Izaguirre CA. Antiviral Res 1997;36:167-177. [PubMed: 9477117]

4. Uziel J, Genet JP. Russ. J. Org. Chem 1997;33:1521-1542.For a review, see:

5. (a) Samanta S, Zhao C-G. J. Am. Chem. Soc 2006;128:7442-7443. [PubMed: 16756289] (b) Dodda R, Zhao C-G. Org. Lett 2006;8:4911-4914. [PubMed: 17020334]

6. Schrader, T.; Kober, R.; Steglich, W. Synthesis. 1986. p. 372-375.

7. Reisser M, Maas G. J. Org. Chem 2004;69:4913-4924. [PubMed: 15255716]

8. (a) Fischer C, Carreira EM. Org. Lett 2001;3:4319-4321. [PubMed: 11784207]For examples, see:Li, C-J.; Wei, C. Chem. Commun. 2002. p. 268-269. (c) Wei C, Li C-J. Green Chem 2002;4:39-41. (d) Wei C, Li C-J. J. Am. Chem. Soc 2002;124:5638-5639. [PubMed: 12010027] (e) Wei C, Li C-J. J. Am. Chem. Soc 2003;125:9584-9585. [PubMed: 12904013] (f) Wei C, Li Z, Li C-J. Org. Lett 2003;5:4473-4475. [PubMed: 14602028] (g) Fischer C, Carreira EM. Org. Lett 2004;6:1497. [PubMed: 15101776] (h) Black DA, Arndtsen BA. Org. Lett 2004;6:1107-1110. [PubMed: 15040734] (i) Benaglia M, Negri D, Dell'Anna G. Tetrahedron Lett 2004;45:8705-8708.Wei, C.; Li, Z.; Li, C-J. Synlett. 2004. p. 1472-1483. (k) Wei C, Mague JT, Li C-J. Proc. Natl. Acad. Sci. U. S. A 2004;101:5749-5754. [PubMed: 15067132] (1) Li Z, Wei C, Chen L, Varma RS, Li C-J. Tetrahedron Lett 2004;45:2443-2446. (m) Ju Y, Li C-J, Varma RS. QSAR Comb. Sci 2004;23:891-894. (n) Bisai A, Singh VK. Org. Lett 2006;8:2405-2408. [PubMed: 16706537] (o) Huang B, Yao X, Li C-J. Adv. Syn. Cat 2006;348:1528-1532.

9. (a) Ji J-X, Au-Yeung TT-L, Wu J, Yip CW, Chan ASC. Adv. Syn. Cat 2004;346:42-44. (b) Ji J-X, Wu J, Chan ASC. Proc. Natl. Acad. Sci. USA 2005;102:11196-11200. [PubMed: 16061808]

10. Hamilton, R.; McKervey, MA.; Rafferty, MD.; Walker, BJ. J. Chem. Soc., Chem. Commun. 1994. p. 37-38.Compounds $\mathbf{2}$ and $\mathbf{5}$ were prepared by using a modified procedure originally reported by Hamilton and co-workers, see:

11. (a) Marin SDL, Martens T, Mioskowski C, Royer J. J. Org. Chem 2005;70:10592-10595. [PubMed: 16323880]The PMP group may be readily deprotected, see:Ref. $9 \mathrm{~b}$ 
Table 1

Optimization of Catalyst and Reaction Conditions ${ }^{a}$

\begin{tabular}{|c|c|c|c|}
\hline & 1a & $\stackrel{\text { st }}{\rightarrow}$ & \\
\hline entry & catalyst & solvent & $\begin{array}{l}\text { yield } \\
(\%)^{b}\end{array}$ \\
\hline 1 & $\mathrm{Zn}(\mathrm{OTf})_{2}, \mathrm{In}(\mathrm{OTf})_{3}, \mathrm{AgOAc}$ & toluene & 0 \\
\hline 2 & $\mathrm{CuBr}_{2}, \mathrm{CuX}(\mathrm{X}=\mathrm{Br}, \mathrm{Cl}, \mathrm{I}), \mathrm{AgNO}_{3}, \mathrm{AgI}$ & toluene & $<10$ \\
\hline 3 & $\mathrm{Sc}(\mathrm{OTf})_{3}$ & toluene & 16 \\
\hline 4 & $\mathrm{Cu}(\mathrm{OTf})_{2}$ & toluene & 36 \\
\hline 5 & $(\mathrm{CuOTf})_{2} \cdot \mathrm{C}_{6} \mathrm{H}_{5} \mathrm{CH}_{3}$ & toluene & 30 \\
\hline 6 & AgOTf & toluene & 62 \\
\hline 7 & AgOTf & hexane & 22 \\
\hline 8 & AgOTf & $\mathrm{CH}_{2} \mathrm{Cl}_{2}$ & 32 \\
\hline 9 & AgOTf & dioxane & 41 \\
\hline 10 & AgOTf & $\mathrm{CH}_{3} \mathrm{CN}$ & 36 \\
\hline $11^{c, d}$ & $\mathrm{AgOTf}$ & toluene & 78 \\
\hline $12^{c, e}$ & $\mathrm{AgOTf}$ & toluene & 72 \\
\hline $13^{c, f}$ & AgOTf & toluene & 94 \\
\hline
\end{tabular}

${ }^{a}$ Unless otherwise indicated, all reactions were carried out with phenylacetylene $(0.75 \mathrm{mmol}), p$-anisidine $(0.50 \mathrm{mmol})$, diethyl $\alpha$-formylphosphonate hydrate $(0.50 \mathrm{mmol})$ and the catalyst $(0.50 \mathrm{mmol}, 10 \mathrm{~mol} \%)$ at $\mathrm{rt}$ in the specified solvent $(6.0 \mathrm{~mL})$ for $12 \mathrm{~h}$.

${ }^{b}$ Yield of isolated product after chromatography.

${ }^{c}$ Reactions were carried out at $\mathrm{rt}$ for $6 \mathrm{~h}$.

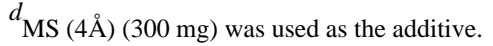

$e^{e} \mathrm{Na}_{2} \mathrm{SO}_{4}(2.5 \mathrm{mmol})$ was used as the additive.

${ }^{\mathrm{MgSO}} 4$ (2.5 mmol) was used as the additive. 
Table 2

Silver(I) Triflate-Catalyzed One-Pot Synthesis of $N$-PMP protected $\alpha$-Aminopropargylphosphonates ${ }^{a}$

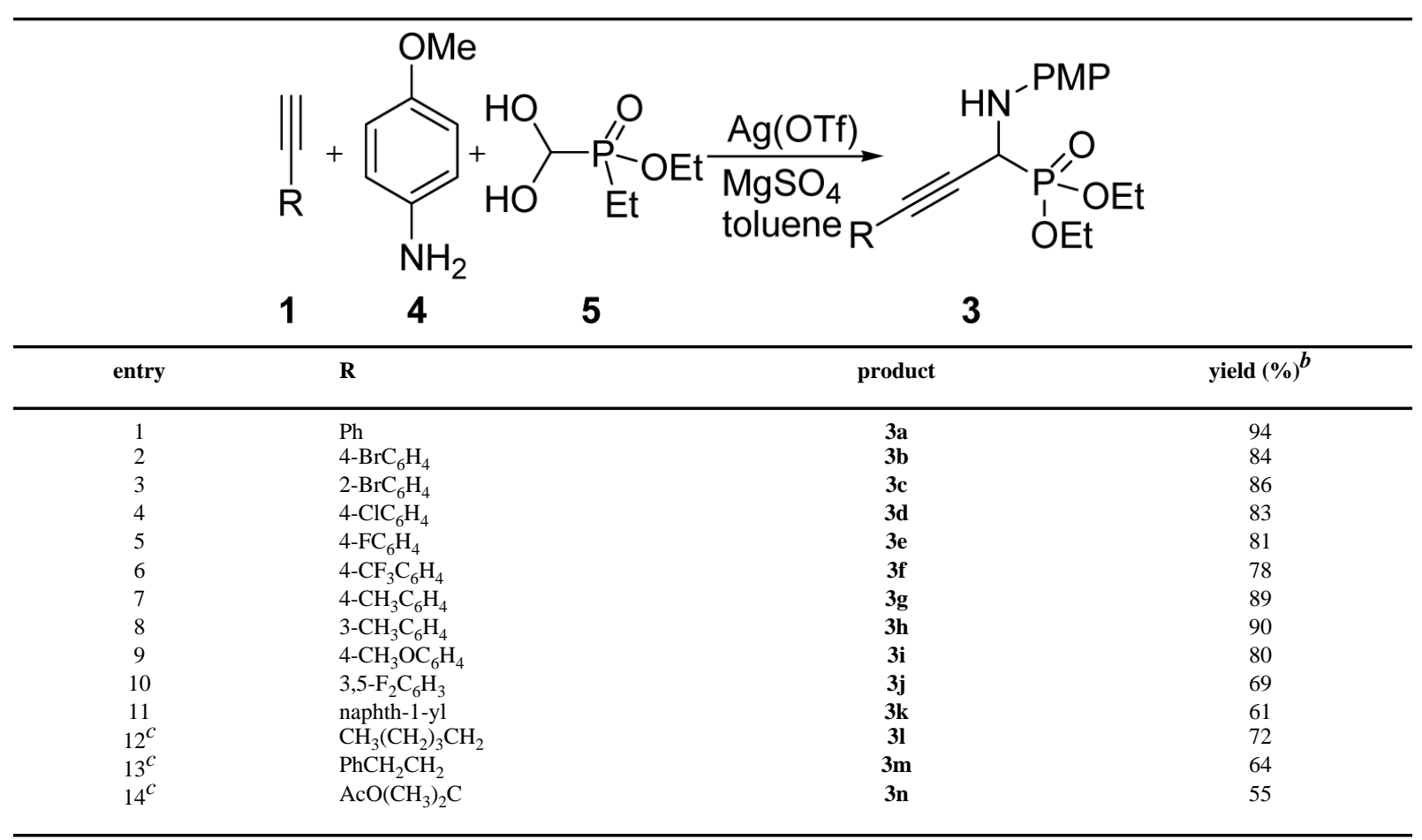

\footnotetext{
${ }^{a}$ Unless otherwise specified, all reactions were conducted with the alkyne $(0.75 \mathrm{mmol}), p$-anisidine $(0.50 \mathrm{mmol})$, diethyl $\alpha$-formylphosphonate hydrate $(0.50 \mathrm{mmol})$, anhydrous $\mathrm{MgSO}_{4}(2.50 \mathrm{mmol})$ and $\mathrm{AgOTf}(0.50 \mathrm{mmol}, 10 \mathrm{~mol} \%)$ in anhydrous toluene $(6.0 \mathrm{~mL})$ at $\mathrm{rt}$ for $6 \mathrm{~h}$.

${ }^{b}$ Yield of isolated product after chromatography.

$c_{\text {The preformed imine } 2}(0.50 \mathrm{mmol})$ was slowly added to a toluene solution $(2.0 \mathrm{~mL})$ of the alkyne $(0.75 \mathrm{mmol})$ and AgOTf $(0.05 \mathrm{mmol})$, and the reaction mixture was stirred at $\mathrm{rt}$ for $24 \mathrm{~h}$.
} 